\title{
A study of indoor radon levels in Iraqi Kurdistan Region, Influencing factors and lung cancer risks
}

\author{
Zakariya A. Hussein $^{(1)^{*}}$, Mohamad S. Jaafar ${ }^{(1)}$ and Asaad H. Ismail ${ }^{(2)^{*}}$ \\ ${ }^{(1)}$ Radiation and Medical Physics, School of Physics, Universiti Sains Malaysia, 11800, Pulau Penang, Malaysia \\ ${ }^{(2)}$ Medical Physics, Physics Department, Education College, Salahaddin University-Erbil, 44002, Iraqi \\ Kurdistan, IRAQ
}

\begin{abstract}
Radon alpha activity concentration has been measured in 8 public hospitals in the three main governorates: Erbil, Duhok and Sulaymaniya -Iraqi Kurdistan region during two seasons summer and winter by using CR-39 nuclear track detectors. The CR-39 detectors were placed in the all hospitals for three floors (ground, first and second). . The highest average radon concentration was found to be in the Shaheed Dr.Aso hospital (Sulaymaniya) in winter season $\left(131.73 \pm 9.42 \mathrm{~Bq} . \mathrm{m}^{-3}\right)$, and the lowest was found in the Erbil Teaching hospital (Erbil) in summer season $\left(30.15 \pm 2.83 \mathrm{~Bq} . \mathrm{m}^{-3}\right)$, this depended on the geological formation, type of building material, ventilation rate and the floor level. Therefore, the results showed that the average radon concentration and annual effective dose decreases gradually as the floor level increases. The highest and lowest of annual effective dose was found in ground and second floor, respectively.

Key words: CR-39NTDs, Indoor radon, lung cancer, ventilation and hospitals
\end{abstract}

\section{Introduction}

Radon is a naturally occurring radioactive gas that originates from the decay of uranium. Due to its relatively longer half life of 3.82 days, the most concerned radon isotope is ${ }^{222} \mathrm{Rn}$. Radon-222 decays and produces a series of short lived particulate daughter products. After inhalation, it may cause significant damage to the delicate inner cells of the bronchioles which may lead to the occurrence of lung cancer [1-2]. Assessment of health effects due to exposure to ionizing radiation from natural sources requires knowledge of its distribution in the environment. The estimated global average annual dose of the population receiving natural radiation equals $2.4 \mathrm{mSv}$, of which one-third is attributed to external and two-thirds to internal exposure [3-4]. The highest component of the annual equivalent dose comes from the inhalation of radon $\left.{ }^{222} \mathrm{Rn}\right)$ and its short-lived alpha-emitting decay products ${ }^{218} \mathrm{Po}$ and ${ }^{214} \mathrm{Po}$. Alpha particles emitted from ${ }^{222} \mathrm{Rn},{ }^{218} \mathrm{Po}$ and ${ }^{214} \mathrm{Po}$ deposit their energies to the tissues of the lungs, as a result, lung cancer might be produced [5-6]. People may be exposed to external and internal radiations by inhalation and ingestion due to background radiations that exist in the environment. Radon exposure occupies 50\% of the average annual dose contribution of population radiation exposure; thus, most of the risks are from the inhalation of radon gas [7]. According to the last research of the risks of radon by Ismail \& Jaafar [8], radon can be making an infertility of men. Therefore, in the present study, beside of measure indoor radon concentration, we have measure most of important that related to estimate a risks of inhalation of radon gas by the workers inside the hospitals. As well as, and to find variation in radon concentration for three floors ground, first, and second.

\section{Materials and methods}

Iraqi Kurdistan region consist of three main governorates; Erbil, Duhok and Sulaymaniya. These areas are different from each other geographical location is shown in Fig. 1. Passive radon dosimeter geometry is a closed-opened chamber into which radon diffuses, and it has been calibrated by Ismail and Jaafar [9]. The schematic diagram of the chamber is shown in Fig. 2. The technique used in this survey is based on CR-39NTDs (Moulding, UK, manufactures the detectors), it has area of $1.5 \times 1.5 \mathrm{~cm}^{2}$ which is fixed by double-stick tape at the bottom of the dosimeter. In the cover there is a hole covered with a 5-mm thick soft sponge. The design of the chamber ensures that all aerosols and radon decay products are deposited on the soft sponge from the outside and that only radon gas. The design of the chamber ensures that the aerosol particles and radon decay products are deposited on the sponge from outside and only radon, among other gases, diffuses through it to the sensitive volume of the chamber. The dosimeters were distributed inside 8 public hospitals in three main regions (Erbil, Duhok and Sulaymaniya) in Iraqi Kurdistan region, in each hospital distributed on three floors (ground, first and second). Nuclear track detector type CR-39 (CR-39NTDs) used to measure track density of alpha particles that emitted from radon and its progeny. During for two seasons summer and winter, 144 pair of exposure chambers (opened-closed chamber) equipped with 288 pieces of CR-39NTDs installed inside 72 rooms for three floors ; 3 rooms in each floor, on the top about $2 \mathrm{~m}$ above the floor. After each season (90 day) of exposure, exposed 
detectors etched in $6 \mathrm{~N} \mathrm{NaOH}$ at $70 \circ \mathrm{C}$ for $10 \mathrm{~h}$. The counting of alpha damage tracks was done using an optical microscope with a magnification of $400 \mathrm{X}$ was used.

\section{Results and discussion}

Average value of indoor radon concentration $\left(\mathrm{C}_{\mathrm{Rn}}\right)$ and annual effective dose $\left(\mathrm{H}_{\mathrm{E}}\right)$ inside public hospitals in Iraqi Kurdistan Region for two seasons summer and winter summarized in Table 1. The highest indoor radon concentration and annual effective dose was found in winter season in Shahid Dr.Aso hospital $\left(131.73 \pm 9.4\right.$ Bq. $\left.\mathrm{m}^{-3}, 3.08 \pm 0.12 \mathrm{mSv} / \mathrm{y}\right)$ and lowest was found in summer in Erbil Teaching hospital $\left(30.15 \pm 2.83 \mathrm{~Bq} . \mathrm{m}^{-3}, 0.8 \pm 0.088 \mathrm{mSv} / \mathrm{y}\right)$ as shown in Fig.3 and Fig.4 . However, it was observed that the values are much lower than the action levels recommended by the International Commission on Radiological Protection (ICRP) [5]. The seasonal variation of radon levels could be attributed to the meteorological conditions, since in winter, these dwellings were poorly ventilated to save energy but they had good ventilation in summer time. This refers to the different building material, ventilation rate, and the geological formation. The geological formation of Erbil governorate different than the geological formation of Duhok and Sulaiminiya . More details about geological formation are listed in Table 2 [10]. Table 3 shows the maximum and minimum radon concentration and annual effective dose for each level. The highest average radon concentration and annual effective dose was found in ground floor in winter season in the Shaheed Dr.Aso hospital ( $141.56 \pm 2.01 \mathrm{~Bq} . \mathrm{m}^{-3}$ ) and lowest was found in second floor in summer season in the Rizgary Teaching hospital $\left(30.86 \pm 2.05\right.$ Bq. $\left.\mathrm{m}^{-3}\right)$, as shown in Fig.5, Fig. 6 shows a combination relation of annual effective dose in different floors in summer and winter seasons . Average indoor radon concentration decreases as the floor level increases, this due to the reduced effect of radon exhalations from the ground. This variation may be attributed to how close or how far the floor is from ground since soil represents the main source of indoor radon. In addition, many other reasons such as the fact that upper floors are better ventilated than lower floors that are exposed to dust and other forms of contaminations.

\section{Conclusion}

Indoor radon concentrations have been measured inside public hospitals in Iraqi Kurdistan region in two seasons' summer and winter. Floor levels and geological formation of the Iraqi Kurdistan hospitals affect on the concentrations of indoor radon and its progeny Locations of the selected hospitals had different geological formation and located in three main governorates: Erbil, Duhok and Sulaymaniya. The present study consisted of two main parts; first was the effect of the geological formation on indoor radon concentration, and this has been investigated. The highest radon concentration was found in winter in the Shaheed Dr. Aso hospital (Sulaymaniya city: mountain region) and lowest in summer in the Erbil Teaching hospital (Erbil city). The second part related to the effects of floor level on the concentration of indoor radon. Therefore, the results showed that the average radon concentration and annual effective dose decreases gradually as the floor level increases. The highest and lowest of annual effective dose was found in ground and second floor, respectively.

\section{Acknowledgement}

The authors deeply thank all the staffs and patients in selected hospitals in Iraqi Kurdistan for their information and a good cooperation.

\section{Reference}

[1]. Durrani S A., (1993). Radon as a health hazard at home: What are the facts?. Nuclear Tracks and Radiation Measurements. 22(1-4) p. 303-317.

[2]. EPA (Environmental Protection Agency), (2010). Consumer's guide to radon reduction; How to fix your home. EPA. 402/K-10/005.

[3]. Durrani, S.A., Ilic, R., (1997). Radon Measurements by Etched Track Detectors: Applications in Radiation Protection, Earth Sciences, and the Environment. World Scientific, Singapore.

[4]. Rahman, S., Matiullah, Rahman, Z., Mati, N., Ghauri, B.M., (2007). Measurement of indoor radon levels in North West Frontier Province and federally administered tribal areas-Pakistan during summer. Radiat. Meas. 42 (2), 304-310.

[5]. ICRP (International Commission on Radiological Protection), (1984). Non-stochastic Effects of Irradiation. ICRP Publication 41. Ann. ICRP. 14.

[6]. Shankarnarayanan K.,(1998). Ionizing radiation and genetic risks. IX. Estimates of frequencies of Mendelian diseases and spontaneous mutation rates in human population. Mutation Research. 411 p.129-178.

[7]. Somlai J , Szeiler G, Szabo P., (2009). Radiation dose of workers originating from radon in the show cave of Tapolca, Hungary. J. of Radio analytical and Nuclear Chemistry. 279(1) p.219-225.

[8]. Ismail A H and Jaafar M S.,(2010). Relationship between radon concentration, ventilation rate and male infertility: A Case study in Iraqi Kurdistan. International Journal of Low Radiation .7(3) p.175-187.

[9]. Ismail A H and Jaafar M S.,(2011). Design and construct optimum dosimeter to detect airborne radon and thoron gas: Experimental study. Nuclear Instruments and Methods in Physics Research B. 269(4) p. 437-439.

[10]. Kamal H. K. and Ali M.S.,(2004). Geological formation in Iraqi Kurdistan : (KAJ) Kurdistan Academicians Journal, 4(1) part A p. 19-39. 
A study of indoor radon levels in Iraqi Kurdistan Region, Influencing factors and lung cancer risks

Table (1) Indoor Radon Concertration and Annual Effective dose inside hospitals in Iraqi Kurdistan Region.

\begin{tabular}{|c|c|c|c|c|l|}
\hline \multirow{2}{*}{ Regions } & \multirow{2}{*}{ Hospital } & \multicolumn{2}{|c|}{ Radon Concentration $(\mathrm{Bq} \mathrm{m}-3)$} & \multicolumn{2}{c|}{ Annual Effective Dose (mSv/y) } \\
\cline { 3 - 6 } & & Winter & Summer & Winter & \multicolumn{1}{c|}{ Summer } \\
\hline \multirow{3}{*}{ Erbil } & Rizgary & $96.50 \pm 9.34$ & $34.03 \pm 3.32$ & $2.13 \pm 0.20$ & $0.925 \pm 0.12$ \\
\cline { 2 - 6 } & Emergency west & $86.45 \pm 9.16$ & $31.346 \pm 2.77$ & $1.93 \pm 0.21$ & $0.893 \pm 0.084$ \\
\cline { 2 - 6 } & Erbil Teaching & $82.13 \pm 10.05$ & $30.15 \pm 2.83$ & $1.84 \pm 0.22$ & $0.813 \pm 0.088$ \\
\cline { 2 - 6 } & Paediatric & $106.24 \pm 10.04$ & $36.9 \pm 3.12$ & $2.44 \pm 0.23$ & $1.075 \pm 0.11$ \\
\hline \multirow{2}{*}{ Duhok } & Azadi Teaching & $113.05 \pm 10.72$ & $43.12 \pm 2.89$ & $2.57 \pm 0.23$ & $1.25 \pm 0.098$ \\
\cline { 2 - 6 } & Emergency Teaching & $102.68 \pm 8.87$ & $41.78 \pm 2.27$ & $2.35 \pm 0.27$ & $1.21 \pm 0.11$ \\
\hline \multirow{2}{*}{ Sulaymaniya } & Shahid Dr. Aso & $131.73 \pm 9.4$ & $52.89 \pm 3.52$ & $3.08 \pm 0.12$ & $1.37 \pm 0.092$ \\
\cline { 2 - 6 } & Shorsh General & $123.62 \pm 7.23$ & $49.2 \pm 2.22$ & $2.91 \pm 0.17$ & $1.31 \pm 0.16$ \\
\hline
\end{tabular}

Table 2: Geological formation of Iraqi Kurdistan region as related to the case study

\begin{tabular}{|c|c|c|c|}
\hline Regions & Hospital & Equilibrium Factor $\quad(\mathrm{F})$ & Building materials \\
\hline \multirow{4}{*}{ Erbil } & Rizgary & \multirow{4}{*}{$\begin{array}{l}\text { Region consists of the plains and hills. It } \\
\text { consists of sandstone, limestone and shale }\end{array}$} & \multirow{4}{*}{$\begin{array}{l}\text { clay brick, cement } \\
\text { concrete, gypsum } \\
\text { and gypsum bord }\end{array}$} \\
\hline & Emergency west & & \\
\hline & Erbil Teaching & & \\
\hline & Paediatric & & \\
\hline \multirow[b]{2}{*}{ Duhok } & Azadi Teaching & \multirow{2}{*}{$\begin{array}{l}\text { Region consists of the plains, sediment logical } \\
\text { and mountains. It consists of marly limestone, } \\
\text { calcarenite shale, sandly limestone and } \\
\text { conglomerate }\end{array}$} & \multirow{2}{*}{$\begin{array}{l}\text { clay brick } \\
\text { slimestone bricks, } \\
\text { cement gypsum } \\
\text { and gypsum bord }\end{array}$} \\
\hline & $\begin{array}{l}\text { Emergency } \\
\text { Teaching }\end{array}$ & & \\
\hline \multirow[b]{2}{*}{ Sulaymaniya } & Shahid Dr. Aso & \multirow{2}{*}{$\begin{array}{l}\text { Region consists of the Rocky Mountains and } \\
\text { valleys. It consists of rocks, limestone, } \\
\text { conglomerate, biogenic limestone, pebbly, } \\
\text { calcarenite and sandstone }\end{array}$} & \multirow{2}{*}{$\begin{array}{l}\text { clay brick } \\
\text { slimestone bricks } \\
\text { and cement } \\
\text { concrete gypsum }\end{array}$} \\
\hline & Shorsh General & & \\
\hline
\end{tabular}

Table (3) Indoor radon concentration and Annual effective dose for different floors in inside hospitals in Iraqi Kurdistan Region.

\begin{tabular}{|l|l|l|l|l|c|}
\hline \multirow{2}{*}{ Hospitals } & \multirow{2}{*}{ Levels } & \multicolumn{2}{c|}{ Radon Concentration (Bq.m-3) } & \multicolumn{2}{c|}{ Annual Effective dose (mSv/y) } \\
\cline { 3 - 6 } & & Winter & Summer & Winter & Summer \\
\hline \multirow{3}{*}{$\begin{array}{c}\text { Rizgary } \\
\text { (Erbil) }\end{array}$} & Ground & $106.23 \pm 2.005$ & $37.5 \pm 2.29$ & $2.34 \pm 0.05$ & $1.01 \pm 0.07$ \\
\cline { 2 - 6 } & First & $95.70 \pm 1.94$ & $33.74 \pm 2.88$ & $2.12 \pm 0.02$ & $0.94 \pm 0.02$ \\
\cline { 2 - 6 } & Second & $87.59 \pm 2.004$ & $30.86 \pm 2.05$ & $1.93 \pm 0.04$ & $0.85 \pm 0.03$ \\
\hline \multirow{3}{*}{$\begin{array}{l}\text { Azadi Teaching } \\
\text { (Duhok) }\end{array}$} & Ground & $124.67 \pm 1.94$ & $46.01 \pm 2.09$ & $2.83 \pm 0.11$ & $1.30 \pm 0.08$ \\
\cline { 2 - 6 } & First & $110.94 \pm 2.04$ & $43.12 \pm 2.06$ & $2.53 \pm 0.18$ & $1.24 \pm 0.085$ \\
\cline { 2 - 6 } & Second & $103.54 \pm 2.15$ & $40.23 \pm 2.98$ & $2.37 \pm 0.06$ & $1.21 \pm 0.1$ \\
\hline \multirow{3}{*}{$\begin{array}{l}\text { Shahid Dr. Aso } \\
\text { (Sulaymany) }\end{array}$} & Ground & $141.56 \pm 2.01$ & $54.79 \pm 1.96$ & $3.30 \pm 0.07$ & $1.43 \pm 0.09$ \\
\cline { 2 - 6 } & First & $130.84 \pm 2.1$ & $51.9 \pm 2.68$ & $3.06 \pm 0.03$ & $1.32 \pm 0.05$ \\
\cline { 2 - 6 } & Second & $122.81 \pm 1.98$ & $49.97 \pm 2.41$ & $2.88 \pm 0.02$ & $1.30 \pm 0.08$ \\
\hline
\end{tabular}




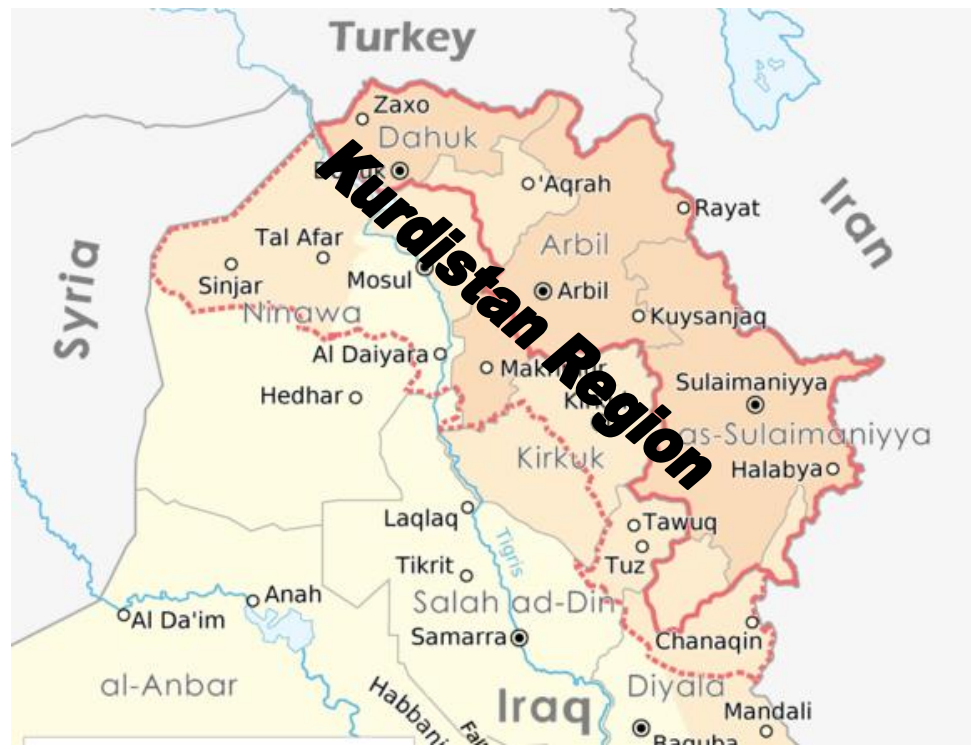

Fig.1: Sketch Map of the area under study (Kurdistan Region)

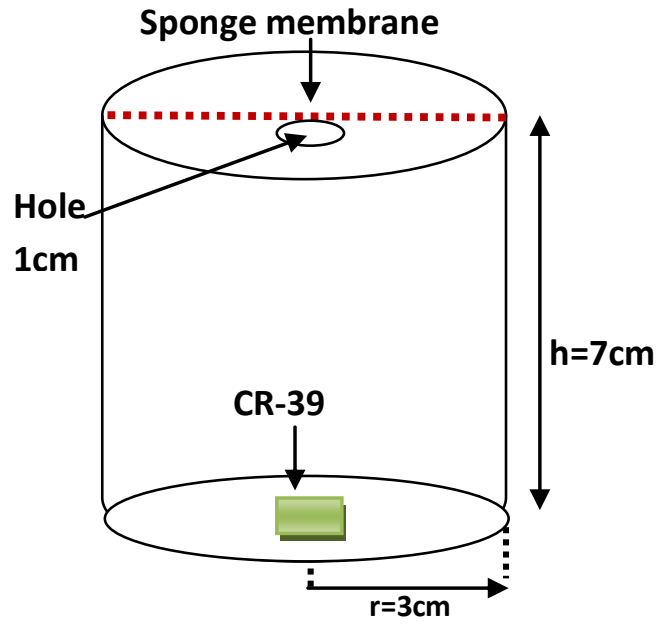

Fig.2: Schematic diagram of the optimum Radon.

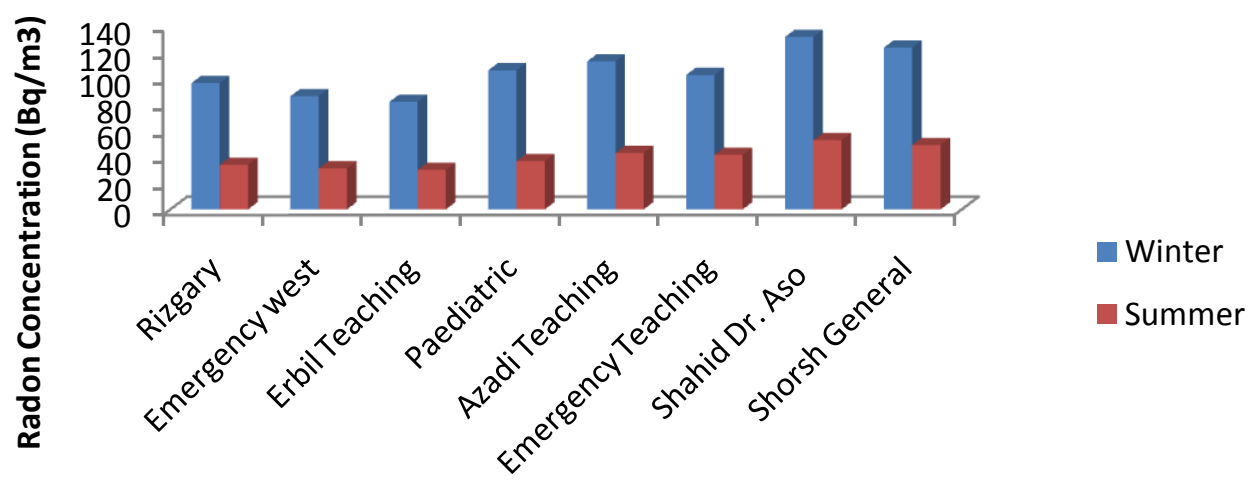

Hospitals

Fig. (3) Measurement of indoor radon concentration in summer and winter inside public hospitals in Iraqi Kurdistan Region. 


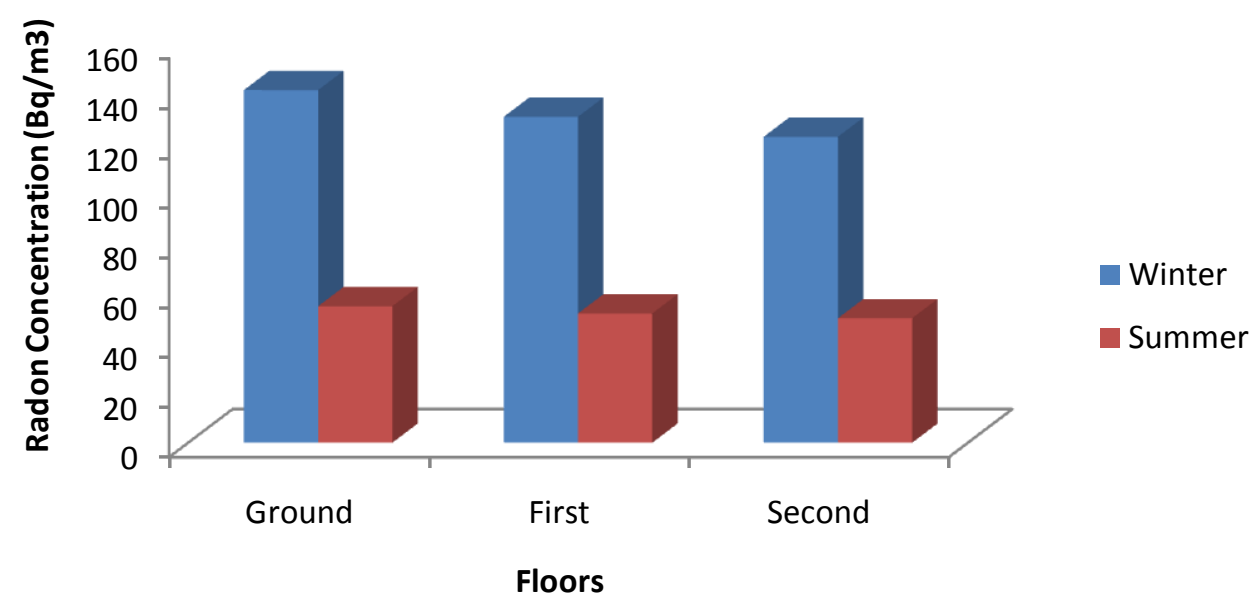

Fig. (5) Variation of Radon Concentration with floor levels in summer and winter seasons in Shaheed Dr. Aso hospital

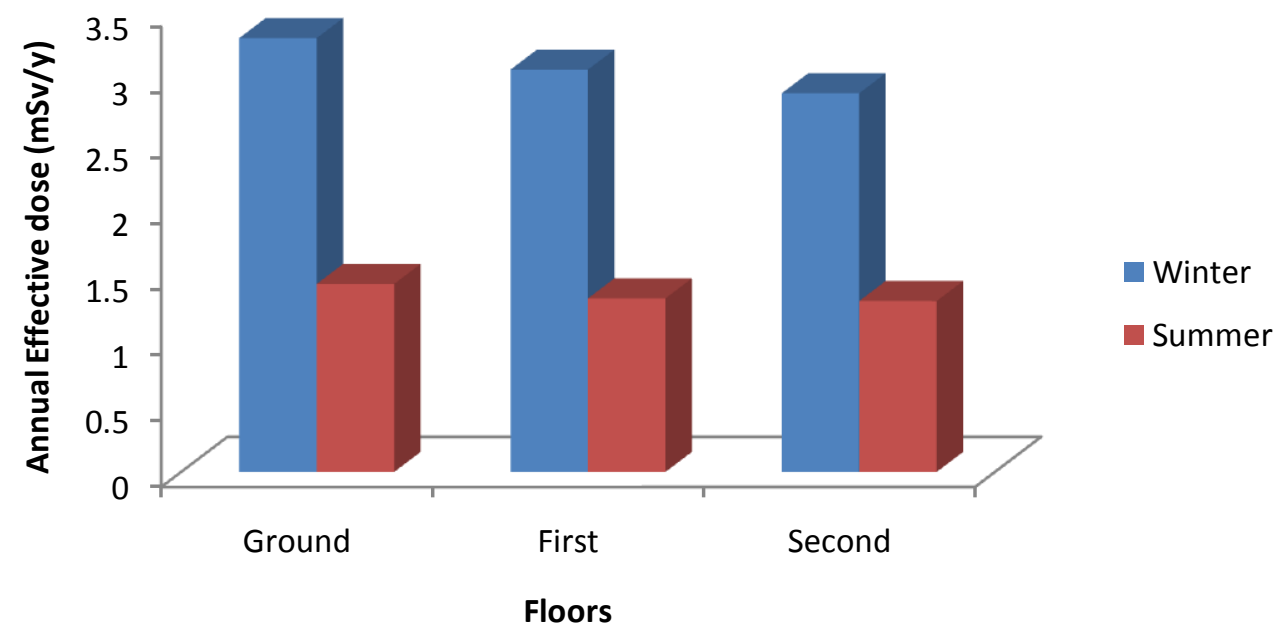

Fig. (6) Variation of Annual Effective dose with floor levels in summer and winter seasons in Shaheed Dr. Aso hospita 